NEWS

\title{
Climate first for Obama transition team
}

\author{
Appointments to key energy positions should reveal the new president's priorities.
}

After eight years out in the cold, Democrats in Washington DC are rushing to warm themselves by the White House fireplace. And although research advocates may have to wait to see major science-policy positions in the new administration filled, a sense of the next president's priorities and style of governance is starting to emerge.

Barack Obama, who defeated John McCain on 4 November for the presidency, swiftly set up a transition team to advise on the hundreds of jobs at senior levels in government that the administration will need filled, many of them, ideally, before the presidential inauguration on 20 January 2009. Running the team are John Podesta, the last of President Bill Clinton's four White House chiefs of staff; Valerie Jarrett, a long-time Obama confidante who is chief executive of The Habitat Company, a Chicago real-estate business; and Peter Rouse, who serves as Obama's chief of staff in the Senate. On 6 November Obama appointed congressman Rahm Emanuel (Democrat, Illinois) to be his White House chief of staff. Announcements of Cabinet positions are expected over the next couple of weeks. The secretaries of the treasury and defence are considered the highest priority, and former Harvard University president Lawrence Summers may reassume the treasury position he held under Clinton. Robert Gates, the incumbent defence secretary, may be asked to stay on, a move that would confirm the team's stated willingness to look at Republicans and independents as well as Democrats.

Podesta, who trained in psychology as an undergraduate before going on to study law, founded the liberal think tank Center for American Progress (CAP) in 2003. The Washington-based group includes a number of leading scholars in science, technology and the environment, including Thomas Kalil another Clinton-White-House veteran, now special assistant to the chancellor for science and technology at the University of California, Berkeley - who served as a science adviser to the Obama campaign.

The transition team declines interviews, but the CAP may provide some clues to how certain issues may fare under an Obama presidency - chief among them energy and climate. In a book published this week, Change for America: A Progressive Blueprint for the 44th President, the think tank outlines its case for a 'national energy council' that would coordinate energy policy among the various agencies and departments with a stake in such issues.

The creation of such a council, under an 'energy czar', would not have the same radical restructuring effect on government as that intended in the United Kingdom's recent creation of a cabinet-level Department of Energy and Climate Change, but it would provide a coordinating role not seen before. "I think it's a great idea," says Bill Becker, a climate policy expert at the University of Colorado in Denver. "A council like this can ensure that comprehensive climate action is delegated to the agencies and that they are coordinated in carrying out a climate action plan."

In the Clinton White House, Vice-President Al Gore took on a de facto role as climate czar. Incoming Vice-President Joe Biden seems unlikely to follow him in this, although he has worked extensively on climate issues as chair of the Senate foreign-relations committee, and it would not be surprising to see him playing a role in the climate negotiations slated for Copenhagen in December 2009, as Gore did in Kyoto. Tim Wirth, a former senator who led climate efforts in the US State Department during the first Clinton administration, says that Podesta, as chief architect of the plan, would automatically leap to the top of any list of people who might assume the suggested czarship - although whether that is what Podesta wants remains unclear.

Other advisers who might be in the frame for the job, or for a seat on the council, would be Dan Kammen, of the University of California, Berkeley, and possibly John Holdren, of Harvard University. For energy- and environment-related cabinet appointments, such as secretary of energy and head of the Environmental Protection Agency (EPA), insiders poo-poo some of the high-profile names that have been bandied about for these jobs, including lawyer and environmental activist Robert F. Kennedy Jr, and Arnold Schwarzenegger, the Republican governor of California. More likely contenders

\section{The congressional outcome}

In last week's elections, 35 Senate seats and all 435 seats in the House of Representatives were contested. Democrats increased their majorities in both houses, although they did not attain the 60 seats in the Senate that would allow them to circumvent some opposition stalling tactics.

Bart Gordon (Democrat, Tennessee) and Ralph Hall (Republican, Texas) will continue to serve as ranking majority and minority members of the House Committee on Science and Technology. The three scientists who serve in the House of Representatives - Democrat Rush Holt of New Jersey, Republican Vern Ehlers of Michigan, and Democrat Bill Foster of Illinois were all re-elected. But Democrat Nick Lampson of Texas, a big supporter of NASA, lost his seat after the boundaries of his district were redrawn.

Rearrangements, rather than comings and goings, may have the most effect on the Hill. In the House, liberal Representative Henry Waxman of California is trying to wrest control of the

energy and commerce committee from John Dingell of Michigan, the longest-serving member in the House, whose district includes a lot of America's troubled, subsidy-seeking auto industry. Waxman might

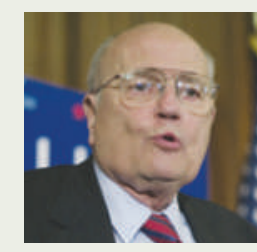

John Dingell. push climate policy more fervently; Dingell, though, would be better placed to get industry on board. In the Senate, 90-year-old Robert Byrd of West Virginia has relinquished control of the appropriations committee, which allocates funding \section{and Transportation} Committee goes to Jay Rockefeller of West Virginia. Inouye, who wanted to be a surgeon before losing an arm in military service, has a demonstrated and geographically unsuprising interest in ocean research. to science and other agencies. He will be replaced by Daniel Inouye of Hawaii, 84, also a Democrat, and Inouye's position as chair of the Commerce, Science

. 
